University of South Carolina

Scholar Commons

$1-19-2008$

\title{
Oligocene Deep Water Export from the North Atlantic and the Development of the Antarctic Circumpolar Current Examined with Neodymium Isotopes
}

\author{
Howie Scher \\ University of South Carolina - Columbia, hscher@geol.sc.edu \\ Ellen E. Martin \\ University of Florida, emartin@geology.ufl.edu
}

Follow this and additional works at: https://scholarcommons.sc.edu/geol_facpub

Part of the Earth Sciences Commons

Publication Info

Published in Paleoceanography, Volume 23, Issue PA1025, 2008, pages 1-12.

Scher, H. D. \& Martin, E. E. (2008). Oligocene deep water export from the North Atlantic and thedevelopment of the Antarctic Circumpolar Current examined withneodymium isotopes.

Paleoceanography, 23 (PA1025), 1-12.

(C) Paleoceanography 2008, American Geophysical Union

This Article is brought to you by the Earth, Ocean and Environment, School of the at Scholar Commons. It has been accepted for inclusion in Faculty Publications by an authorized administrator of Scholar Commons. For more information, please contact digres@mailbox.sc.edu. 


\title{
Oligocene deep water export from the North Atlantic and the development of the Antarctic Circumpolar Current examined with neodymium isotopes
}

\author{
Howie D. Scher ${ }^{1,2}$ and Ellen E. Martin ${ }^{1}$ \\ Received 28 November 2006; revised 26 August 2007; accepted 26 September 2007; published 19 January 2008.
}

[1] Neodymium $(\mathrm{Nd})$ isotopes were measured on 181 samples of fossil fish teeth recovered from Oligocene to Miocene sections at Ocean Drilling Program Site 1090 (3700 m water depth) on Agulhas Ridge in the Atlantic sector of the Southern Ocean. A long-term decreasing trend toward less radiogenic Nd isotope compositions dominates the record. This trend is interrupted by shifts toward more radiogenic compositions near the early/late Oligocene boundary and the Oligocene/Miocene boundary. Overall, $\varepsilon_{\mathrm{Nd}}$ values at Agulhas Ridge are more radiogenic than at other Atlantic locations, and are similar to those at Indian Ocean locations. The pattern of variability is remarkably similar to Nd isotope results from Walvis Ridge (South Atlantic) and Ninetyeast Ridge (Indian Ocean). In contrast, Agulhas Ridge and Maud Rise Nd isotope records do not show similar patterns over this interval. Results from this study indicate that deep water in the Atlantic flowed predominantly from north to south during the Oligocene and Miocene, and that export of Northern Component Water (NCW) to the Southern Ocean increased in the late Oligocene. There is also evidence for efficient exchange of deep waters between the Atlantic sector of the Southern Ocean and the Indian Ocean, although the direction of deep water flow is not entirely clear from these data. The shifts to more radiogenic Nd isotopic compositions most likely represent increases in the flux of Pacific waters through Drake Passage, and the timing of these events reflect development of a mature Antarctic Circumpolar Current (ACC). The relative timing of increased NCW export and ACC maturation support hypotheses that link deep water formation in the North Atlantic to the opening of Drake Passage.

Citation: Scher, H. D., and E. E. Martin (2008), Oligocene deep water export from the North Atlantic and the development of the Antarctic Circumpolar Current examined with neodymium isotopes, Paleoceanography, 23, PA1205, doi:10.1029/2006PA001400.

\section{Introduction}

[2] The circulation of deep water in the oceans is controlled by density driven, or thermohaline, oceanic overturning. In this paradigm, upwelling of abyssal water is balanced by the formation of dense bottom water in isolated high-latitude basins [Stommel, 1958]. Presently, upwelling brings $34.5 \pm$ $17.5 \mathrm{~Sv}\left(\mathrm{~Sv}=10^{6} \mathrm{~m}^{3} / \mathrm{s}\right)$ of deep water to the surface, and up to half of this occurs in the latitude band of Drake Passage through wind driven Ekman divergence [Hellerman and Rosenstein, 1983; Ganachaud and Wunsch, 2000]. Deep water replenishment takes place in the North Atlantic (15-20 Sv [Broecker, 1991]) and around Antarctica (2-5 Sv [Weiss et al., 1979]). However, these patterns of ocean circulation are transient features because deep water formation areas, circulation pathways, and upwelling areas continuously adjust to changes in climate and continental configuration.

\footnotetext{
${ }^{1}$ Department of Geological Sciences, University of Florida, Gainesville, Florida, USA.

${ }^{2}$ Now at Ocean Sciences Department, Institute of Marine Sciences, University of California, Santa Cruz, California, USA.
}

Copyright 2008 by the American Geophysical Union. 0883-8305/08/2006PA001400\$12.00
[3] Global climate and geography have undergone major changes over the course of the Cenozoic. Notably, a long-term deterioration from early Cenozoic greenhouse conditions culminated in a large Antarctic ice sheet around $34 \mathrm{Ma}$ [Zachos et al., 2001]. The dispersal of Southern Hemisphere landmasses opened interocean connections in the Southern Ocean and closed them in the tropics. As a result of these changes, deep water circulation during the Oligocene and Miocene was transitional between the early Cenozoic mode, when deep water primarily formed in the Southern Ocean [Pak and Miller, 1992; Thomas et al., 2003], and the presentday mode, with bipolar deep water formation. Here Southern Ocean Deep Water (SODW) refers to deep waters exported from the Atlantic and/or Indian sectors of the Southern Ocean during the early Cenozoic [Thomas et al., 2003]. It is during the transitional interval that deep water production in the Nordic Seas commenced [Davies et al., 2001]. There is evidence that the resulting water mass, referred to as Northern Component Water (NCW), began to influence the Southern Ocean during the Oligocene [Wright and Miller, 1993; Via and Thomas, 2006].

[4] From the little that is known about the mode of thermohaline circulation during the Oligocene and Miocene, it is clear that the development of the Southern Ocean was a critical factor during this transitional period. The Antarctic Circumpolar Current (ACC) developed as Antarctica sepa- 
rated from South America and Australia, forming Drake Passage and the Tasmanian Gateway. Conditions for a proto-ACC were met during the late Eocene [Stickley et al., 2004; Eagles et al., 2006; Scher and Martin, 2006], but a modern-type ACC was delayed until continental fragments blocking a deep passageway at Drake Passage began to clear [Barker, 2001]. Onset of a modern-type ACC around the Oligocene/Miocene boundary is suggested by erosion of the circum-Antarctic seafloor [Pfuhl and McCave, 2005; Lyle et al., 2007]; however, a deep passageway through Drake Passage may have formed in the early Oligocene [Livermore et al., 2007]. It is important to understand the steps in the evolution of the ACC to test hypotheses that relate the opening of Drake Passage to the onset of NCW production and export through different physical mechanisms. Toggweiler and Samuels [1993, 1995] proposed that deep water formation in the North Atlantic is directly related to wind stress (and hence upwelling) in the Southern Ocean. Moreover, Mikolajewicz et al. [1993] proposed that deep water formation in the North Atlantic is stimulated by the suppression of deep water exported from the Southern Ocean.

[5] To better understand how and why thermohaline circulation changed during the Oligocene and Miocene, the evolution of the ACC and the relative timing of increased export of NCW into the Southern Ocean must be further constrained. The Atlantic sector of the Southern Ocean was ideally positioned to monitor the inflow of disparate water masses as patterns of deep water circulation reorganized. Pacific throughflow via Drake Passage and NCW export from the North Atlantic carried very distinct neodymium $(\mathrm{Nd})$ isotope fingerprints $\left({ }^{143} \mathrm{Nd} /{ }^{144} \mathrm{Nd}\right.$ ratios) during the Oligocene and Miocene [Burton et al., 1997; Ling et al., 1997]. Monitoring changes in the $\mathrm{Nd}$ isotopic composition of seawater in the Atlantic sector over this interval provides a useful way to test different circulation scenarios that have been proposed during this transitional period.

[6] This paper presents $\mathrm{Nd}$ isotope data from fish teeth extracted from sediments deposited during the early Oligocene to early Miocene on Agulhas Ridge in the Atlantic sector of the Southern Ocean. Agulhas Ridge is situated near the present-day boundary between North Atlantic Deep Water (NADW) and Circumpolar Deep Water [Gersonde et al., 1999a]; thus both the organization of the ACC and the onset of deep water export from the North Atlantic are expected to influence this location over the investigated time interval. $\mathrm{Nd}$ isotope results are also compared to the Oligocene and Miocene glaciations to determine if the record has been overprinted by terrigenous inputs from Antarctica. Results from this study are then evaluated relative to published $\mathrm{Nd}$ isotope records to examine different water mass mixing scenarios over the investigated interval and constrain the timing of ACC development relative to other circulation changes. Ultimately, these results are used to test the hypothesis that the opening of Drake Passage helped to bring about deep water formation in the North Atlantic.

\section{Nd Isotopes in Paleoceanography}

[7] Neodymium isotopes $\left({ }^{143} \mathrm{Nd} /{ }^{144} \mathrm{Nd}\right)$ exhibit quasiconservative behavior in seawater so that cores of water masses have distinct isotopic compositions that reflect the age and lithology of surrounding lithosphere. It is conventional to express differences in ${ }^{143} \mathrm{Nd} /{ }^{144} \mathrm{Nd}$ ratios in epsilon notation $\left(\varepsilon_{\mathrm{Nd}}\right)$, which represents the deviation from the chondritic uniform reservoir [DePaolo and Wasserburg, $1976]$ in parts per $10^{4}$. Neodymium isotopic compositions vary considerably over Earth's surface as a result of the distribution of young and old crustal ages, and this pattern is imparted to seawater. For example the $\varepsilon_{\mathrm{Nd}}$ value of NADW is -13.5 [Piepgras and Wasserburg, 1987], which reflects extremely nonradiogenic Nd draining into the Labrador Sea from the ancient terrains of the Canadian Shield, whereas the $\varepsilon_{\mathrm{Nd}}$ value of Pacific Deep Water is -4 to -6 [Piepgras and Jacobsen, 1988], which reflects young arc volcanics in the circum-Pacific. Continental weathering is the predominant source of $\mathrm{Nd}$ to the oceans and $\mathrm{Nd}$ isotopes are not fractionated in marine chemical and biological pathways. Thus $\varepsilon_{\mathrm{Nd}}$ values in seawater can only be changed by the addition of a new component of Nd. For example, in the South Atlantic the $\varepsilon_{\mathrm{Nd}}$ value of NADW is $\sim-11$ [Jeandel, 1993], reflecting mixing with Antarctic Bottom Water and AAIW $\left(\varepsilon_{\mathrm{Nd}}=-8\right)$, which in turn have more radiogenic signatures due to mixing with Pacific seawater.

[8] Neodymium isotopic compositions of authigenic ferromanganese crusts and fossil fish teeth in marine sediments exhibit secular variability on tectonic timescales [Burton et al., 1997; Ling et al., 1997; O'Nions et al., 1998; Frank et al., 2003; Thomas et al., 2003; Scher and Martin, 2004; Thomas, 2004; van de Flierdt et al., 2004; Frank et al., 2006; Martin and Scher, 2006; Scher and Martin, 2006; Via and Thomas, 2006; Thomas and Via, 2007]. These sedimentary components incorporate $\mathrm{Nd}$ at or near the sediment-water interface and the primary $\mathrm{Nd}$ isotope signal is resistant to alteration during diagenetic processes [Martin and Haley, 2000; Frank, 2002; Martin and Scher, 2004]. Two competing signals are embedded in long-term variability of $\mathrm{Nd}$ isotopes at a given location: (1) changes in $\mathrm{Nd}$ inputs derived from continental weathering and (2) changes in the proportions of different water masses. Deciphering the relative roles of these two processes is fundamental to the evaluating the paleoceanographic significance of long-term $\mathrm{Nd}$ isotope records. In the Southern Ocean, secular variability of $\varepsilon_{\mathrm{Nd}}$ values has been attributed to mixing of Pacific, Atlantic, and possibly other water masses [Frank et al., 2002; Scher and Martin, 2006; Via and Thomas, 2006; Thomas and Via, 2007] as the ACC developed. However, the response of Southern Ocean $\varepsilon_{\mathrm{Nd}}$ values to changes in Antarctic weathering inputs as a result of Oligocene and Miocene glacial advances has not been examined directly.

\section{Materials and Methods}

\subsection{Site Description}

[9] ODP Site 1090 is presently located at $42^{\circ} 55^{\prime} \mathrm{S}, 8^{\circ} 54^{\prime} \mathrm{E}$ on the southern flank of Agulhas Ridge in the Atlantic sector of the Southern Ocean in 3700 meters of water (Figures 1 and 2). Drilling at this site recovered $400 \mathrm{~m}$ of sediment. Lower Miocene to middle Eocene sediments were unexpectedly encountered below an unconformity at $\sim 70 \mathrm{mcd}$. Recovery of this sequence was very good as a 


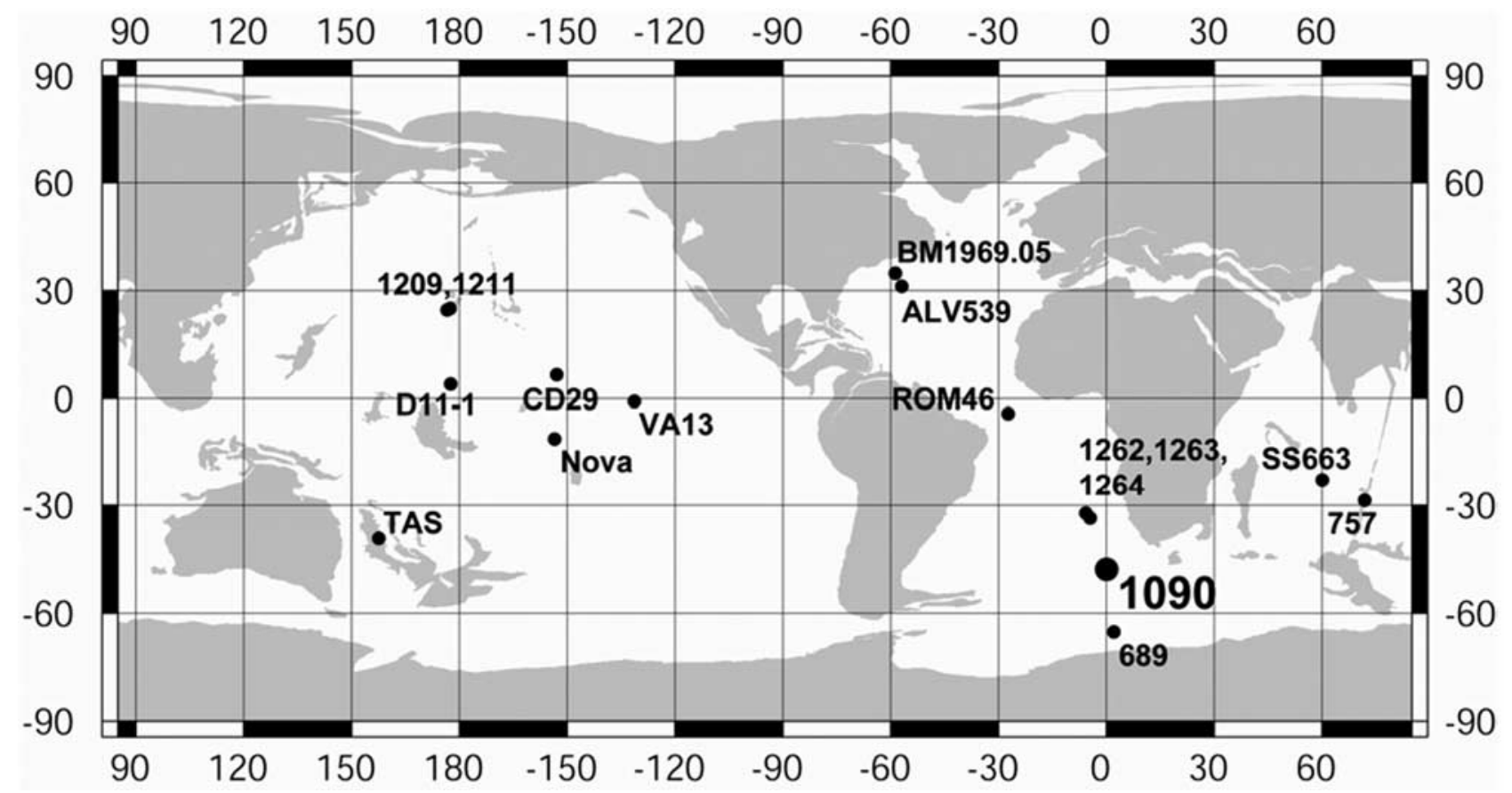

Figure 1. A plate tectonic reconstruction for $30 \mathrm{Ma}$ showing the location of the study site and other locations discussed in the text. This map was generated by the Ocean Drilling Stratigraphic Network (http://www.odsn.de/).

result of its shallow burial; however, drilling disturbances occur below $\sim 347$ mcd in the extended barrel core $(\mathrm{XCB})$ section. Sedimentation rates are relatively high (6$30 \mathrm{~m} / \mathrm{Ma}$ ). Deposition appears to have been continuous in middle Eocene to lower Miocene sections with the exception of an unconformity at $\sim 221 \mathrm{mcd}$, resulting in a $\sim 3 \mathrm{Ma}$ hiatus, where much of the lower Oligocene is missing (Figure 3). This unconformity is attributed to the acceleration of bottom currents around Agulhas Ridge [Wildeboer Schut et al., 2002]. Sediments in the middle Eocene to lower Miocene sequence are composed of calcareous ooze and mud-bearing diatom and nannofossil ooze.

[10] Agulhas Ridge formed prior to Cretaceous time [Gersonde et al., 1999a]. There are two competing hypotheses that account for the formation of Agulhas Ridge with different implications for the paleodepth correction for ODP Site 1090. Agulhas Ridge may be related to hot spot activity [e.g., Hartnady and le Roex, 1985], in which case a depth correction is required. Alternatively, it may have formed from thrusting of the South American plate over the African plate [Gersonde et al., 1999a], which does not require a depth correction. There is not adequate tectonic evidence to support genesis related to a hot spot [Gersonde et al., 1999a]; thus no depth correction was applied to ODP Site 1090 during the period of interest (42-17 Ma). Tectonic reconstructions of the South Atlantic for the middle Eocene indicate that Site 1090 was located at approximately $50^{\circ} \mathrm{S}$, $15^{\circ} \mathrm{E}$. Over the period of interest the site moved $5^{\circ}-6^{\circ}$ to the east and $2^{\circ}-3^{\circ}$ to the north, although the position with respect to Africa did not change.

\subsection{Age Model}

[11] For the section above the unconformity $(70-221 \mathrm{mcd})$ the fit of the polarity zone pattern to the geomagnetic polarity timescale (GPTS) [Cande and Kent, 1995] is unequivocal [Channell et al., 2003]. Below the unconformity, the magnetostratigraphy was fit to the GPTS with the aid of $\mathrm{Sr}$ and $\mathrm{O}$ isotope chemostratigraphy and calcareous nannofossil datums [Channell et al., 2003]. Drilling disturbances below $\sim 347$ mod resulted in a poor magnetostratigraphy in the XCB section. Planktonic foraminifer datums [Berggren et al., 1995; Galeotti et al., 2002] and the depth of the $18 \mathrm{n} / 19 \mathrm{r}$ boundary determined from the shipboard magnetic stratigraphy [Gersonde et al., 1999b] were used to extend the age model to the base of the core [Scher and Martin, 2006].

\subsection{Sample Preparation}

[12] Bulk samples composed of 30-40 cc from ODP Site 1090 were oven-dried at $50^{\circ} \mathrm{C}$, soaked in DI water to disaggregate the sediment and wet sieved. Fossil fish teeth were handpicked from the $>125 \mu \mathrm{m}$ fraction. Samples were cleaned and inspected for sediment adhering to surfaces and within cavities. Prior to column chemistry, all samples were treated using a reductive/oxidative cleaning protocol designed to remove ferromanganese (Fe-Mn) oxide coatings [Boyle, 1981; Boyle and Keigwin, 1985; Rosenthal et al., 1997]. After cleaning, samples were weighed and transferred to clean microcentrifuge tubes for dissolution. Dissolved samples were transferred to Teflon beakers, evaporated to dryness, and several were spiked with ${ }^{149} \mathrm{Sm}$ and ${ }^{150} \mathrm{Nd}$ enriched solutions for $\mathrm{Sm}$ and $\mathrm{Nd}$ concentration determinations by isotope dilution. After spiking, 

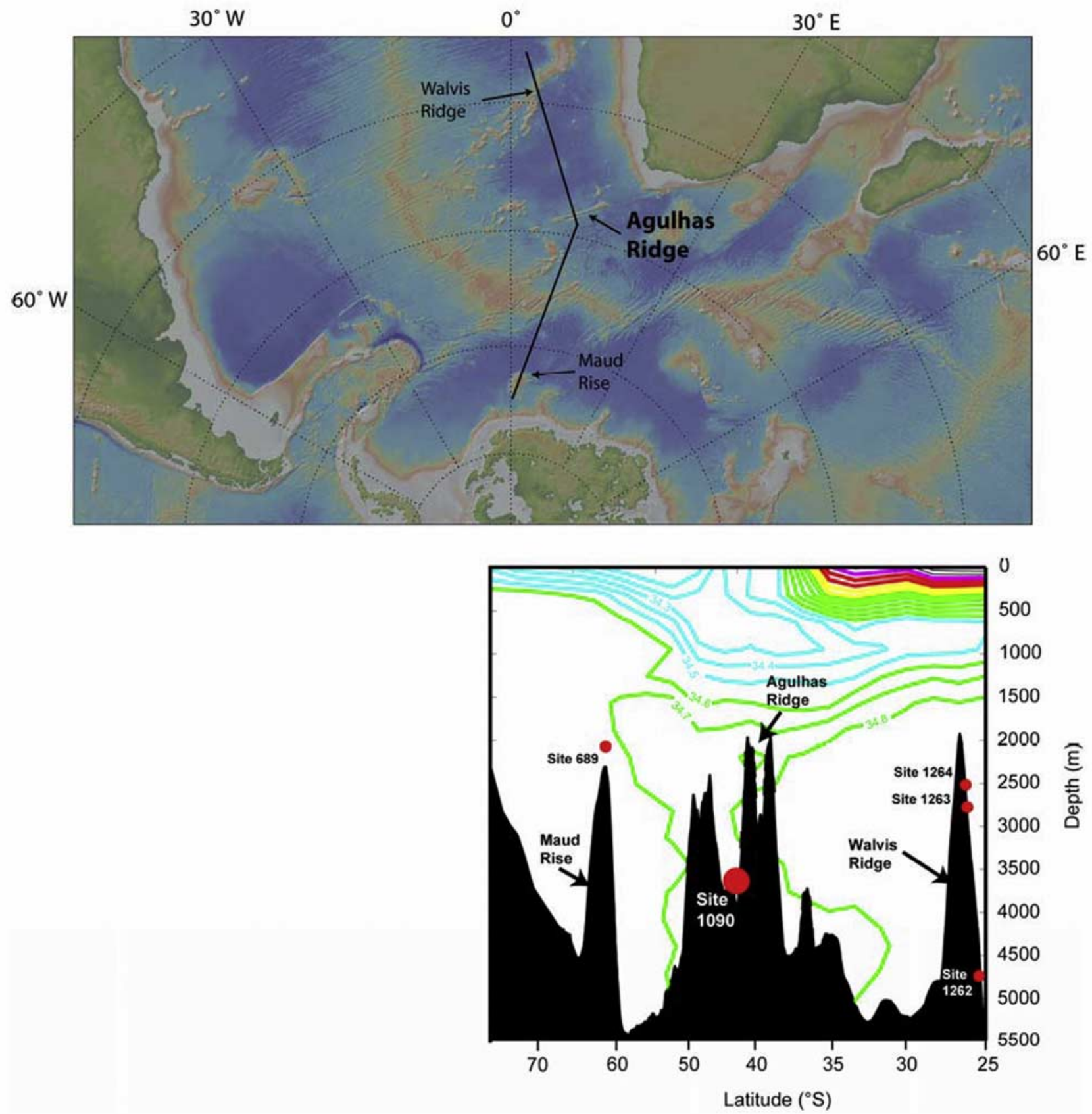

Figure 2. Meridional cross section through the South Atlantic and Southern Ocean showing the locations of Walvis Ridge, Agulhas Ridge, Maud Rise, and the study location. The inset shows the crosssection location. Seafloor bathymetry is from the Antarctic Bathymetry data set of the Marine Geoscience Data System. A contoured cross section of salinity measurements along $2^{\circ} \mathrm{E}$ has been overlain to show present-day water masses. Salinity data were culled from the EPIC data server managed by the Pacific Marine Environmental Laboratory and NOAA.

samples were dried again and passed through two sets of columns: the first to collect $\mathrm{Sr}$ and bulk rare earth elements, and the second to isolate $\mathrm{Sm}$ and $\mathrm{Nd}$ [Scher and Martin, 2004].

\subsection{Isotopic Analysis}

[13] Isotopic ratios of $\mathrm{Sm}$ and $\mathrm{Nd}$ were measured on a Micromass sector 54 thermal ionization mass spectrometer at the University of Florida using an analytical procedure similar to that of Scher and Martin [2004]. Nd isotopes were measured as oxides $\left(\mathrm{NdO}^{+}\right)$. Samples were loaded onto zone-refined Re filaments with silica gel. Beams of $0.5 \mathrm{~V}$ for monitor peak ${ }^{142} \mathrm{Nd}^{16} \mathrm{O}$ were measured for 200 ratios in dynamic mode. Mass fractionation was corrected to ${ }^{162} \mathrm{NdO} /{ }^{160} \mathrm{NdO}=0.722254$. Replicate analyses of the international $\mathrm{Nd}$ standard JNdi-1 over several years yielded 


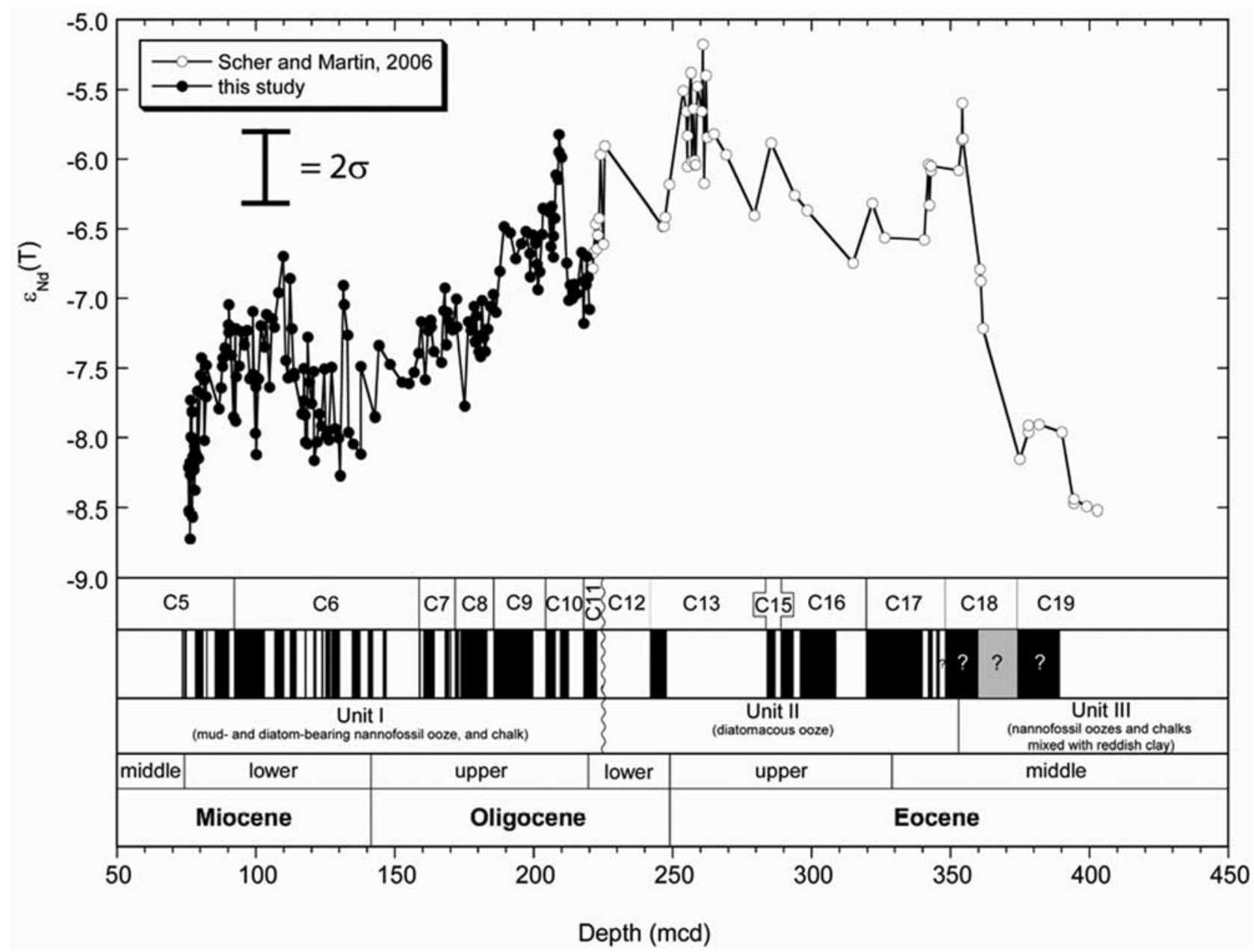

Figure 3. The $\varepsilon_{\mathrm{Nd}}(\mathrm{T})$ values for ODP Site 1090 shown on a depth scale; data from this study (solid circles) and data from Scher and Martin [2006] (open circles) are shown. The error bar represents $2 \sigma$ error based on replicate analyses of the JNdi-1 standard. Lithologic summary is based on work by Diekmann et al. [2004]. Polarity stratigraphy is from Channell et al. [2003].

$0.512102( \pm 0.000014,2 \sigma$ external reproducibility, $\mathrm{n}=122)$. This external reproducibility corresponds to a minimum error of $\pm 0.3 \varepsilon_{\mathrm{Nd}}$ units $(2 \sigma)$.

[14] To determine the reproducibility of $\mathrm{Nd}$ isotopic measurements of different fish teeth from the same depth interval, 17 pairs of samples consisting of 3-5 teeth each were processed and analyzed in parallel. These sample replicates yielded an average sample reproducibility of $0.1 \varepsilon_{\mathrm{Nd}}$ units, with a total range from 0 to $0.6 \varepsilon_{\mathrm{Nd}}$ units. These results indicate that $\mathrm{Nd}$ isotopic variability between teeth in the same depth interval is statistically insignificant. Within-run $2 \sigma$ values of measured samples are reported in the supplemental data file. The Sm isotopic composition of 10 samples yielded an average ${ }^{147} \mathrm{Sm} /{ }^{144} \mathrm{Nd}$ value of 0.1338 from which $\varepsilon_{\mathrm{Nd}}(\mathrm{T})$ values were calculated (see auxiliary material $\left.^{1}\right)$. $\varepsilon_{\mathrm{Nd}}(\mathrm{T})$ values incorporate an age-dependent

\footnotetext{
${ }^{1}$ Auxiliary materials are available at ftp://ftp.agu.org/apend/pa/ 2006 pa001400.
}

correction for the radiogenic ingrowth of ${ }^{147} \mathrm{Sm}$. This correction ranged from 0.1 to $0.3 \varepsilon_{\mathrm{Nd}}$ units depending on the age of the sample.

\section{Results}

[15] An overall decrease in $\varepsilon_{\mathrm{Nd}}(\mathrm{T})$ occurred from the early Oligocene to the middle Miocene (Figures 3 and 4); however, short-term shifts to more radiogenic values are superimposed on this $15 \mathrm{Ma}$ trend. Just above the hiatus in the early Oligocene $\varepsilon_{\mathrm{Nd}}$ values are approximately -7.1 . At $28.8 \mathrm{Ma}, \varepsilon_{\mathrm{Nd}}$ values increase to -5.8 during a pronounced excursion. At $27.3 \mathrm{Ma}, \varepsilon_{\mathrm{Nd}}$ values undergo a prominent decrease to less radiogenic values, which is followed by a long-term decreasing trend until $22.8 \mathrm{Ma}$. From 22.8 to $20 \mathrm{Ma} \varepsilon_{\mathrm{Nd}}$ values again increase to more radiogenic values. A subsequent step to less radiogenic values occurs at 


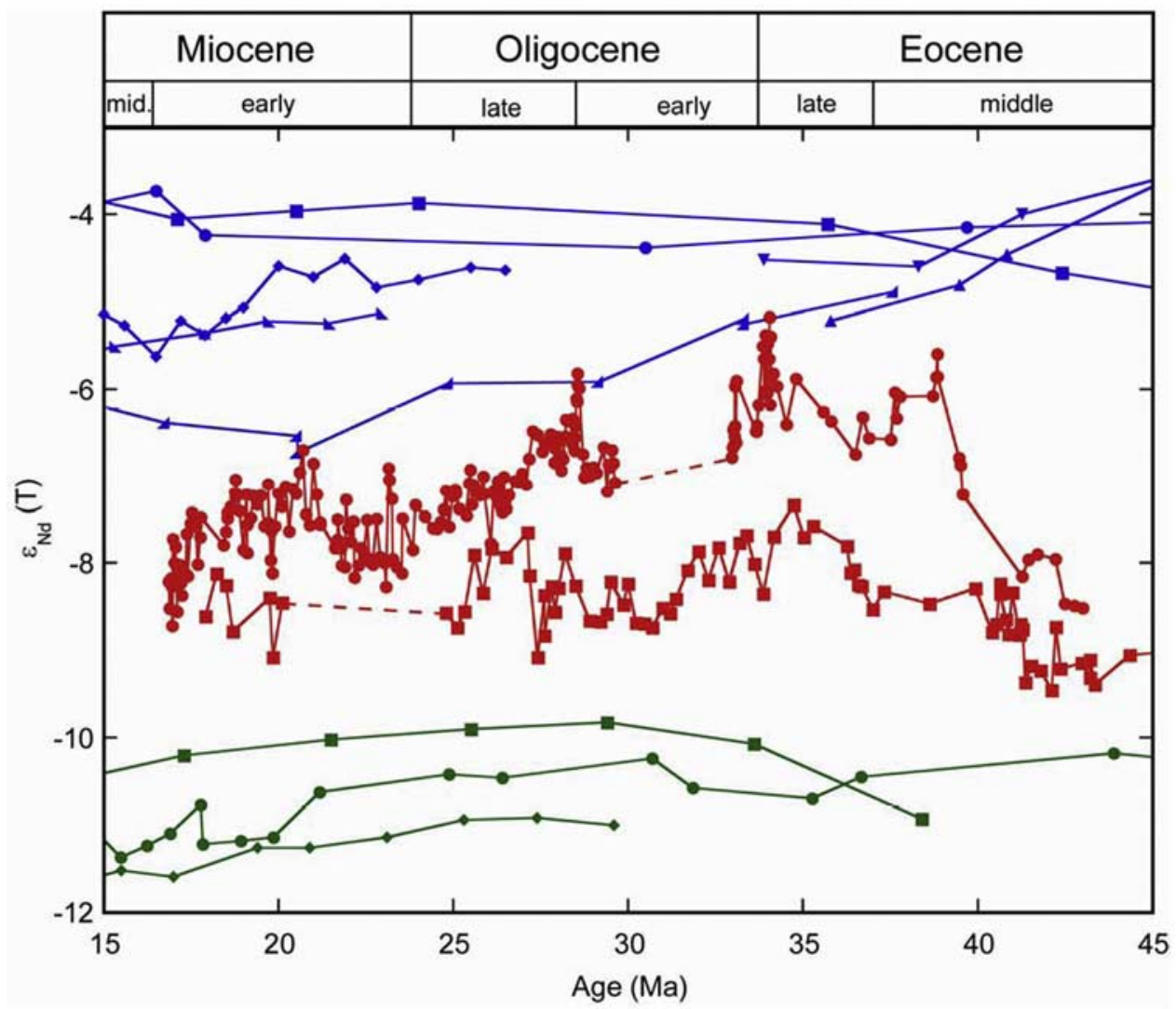

Figure 4. The $\varepsilon_{\mathrm{Nd}}$ records from selected locations over the time interval relevant to this study. Long dashed lines represent hiatuses. Records are color coded by ocean basin. Pacific Ocean locations are: FeMn crusts D11-1 (blue circles), CD29-2 (blue squares), and VA13 (blue diamonds) [Ling et al., 1997]; Fe-Mn crusts Nova (blue triangles with right upward slope) and Tasman (blue triangles with left upward slope) [van de Flierdt et al., 2004]; and ODP Sites 1209 (blue downward pointing triangles) and 1211 (blue upward pointing triangles) [Thomas, 2004]. Atlantic Ocean locations are: Fe-Mn crust BM1969.05 (green circles) [Burton et al., 1997], Fe-Mn crust ALV539 (green squares) [O'Nions et al., 1998], and FeMn crust ROM46 (green diamonds) [Frank et al., 2003]. Southern Ocean locations are: ODP Site 689 (red squares) [Scher and Martin, 2004] and ODP Site 1090 (red circles) [Scher and Martin, 2006].

17.2 Ma, bringing $\varepsilon_{\mathrm{Nd}}$ values to -8.5 in the middle Miocene at the top of the section.

\section{Discussion}

\subsection{Long-Term Decreasing Trend}

[16] The long-term decreasing trend at Agulhas Ridge indicates that a source of nonradiogenic $\mathrm{Nd}$ began to influence the study area in the early Oligocene. Two likely sources of nonradiogenic $\mathrm{Nd}$ are: (1) glacial weathering of Antarctic basement, which contains vast tracts of ancient crust which have nonradiogenic compositions and (2) a water mass carrying a nonradiogenic Nd signature.

\subsubsection{Assessing the Role of Antarctic Glaciation}

[17] The interplay between mechanical and chemical weathering during Oligocene and Miocene Antarctic glaciations probably resulted in a dramatic increase in the flux of dissolved material into the Southern Ocean [Zachos et al., 1999; Ravizza and Peucker-Ehrenbrink, 2003]. Detrital $\varepsilon_{\mathrm{Nd}}$ of core top sediments from Weddell Sea and Dronning
Maud Land sectors of the circum-Antarctic average $-12.0 \varepsilon_{\mathrm{Nd}}$ [Roy et al., 2007; van de Flierdt et al., 2007], which reflect terrigenous inputs sourced from ancient basement on Antarctica. However, because acquisition of the $\mathrm{Nd}$ isotopic signature of water masses is not fully understood, the long-term impact of an increase in Antarctic weathering products on deep water at Agulhas Ridge is difficult to predict. If glacial weathering of Antarctic basement was an important factor in determining the $\mathrm{Nd}$ isotopic composition of SODW, the major Oligocene and Miocene glaciations [Miller et al., 1987, 1991] would probably be associated with less radiogenic $\mathrm{Nd}$ isotopic compositions at Agulhas Ridge. Moreover, if the dissolved flux coming off Antarctica increased during deglaciations as a result of rock exposure, it is expected that decreasing values would follow Oligocene and Miocene glaciations. However, if the period of increased weathering associated with glaciations is short relative to the overall duration of the decreasing trend, it is unlikely that $\mathrm{Nd}$ isotopes will respond owing to its short residence time in seawater. 


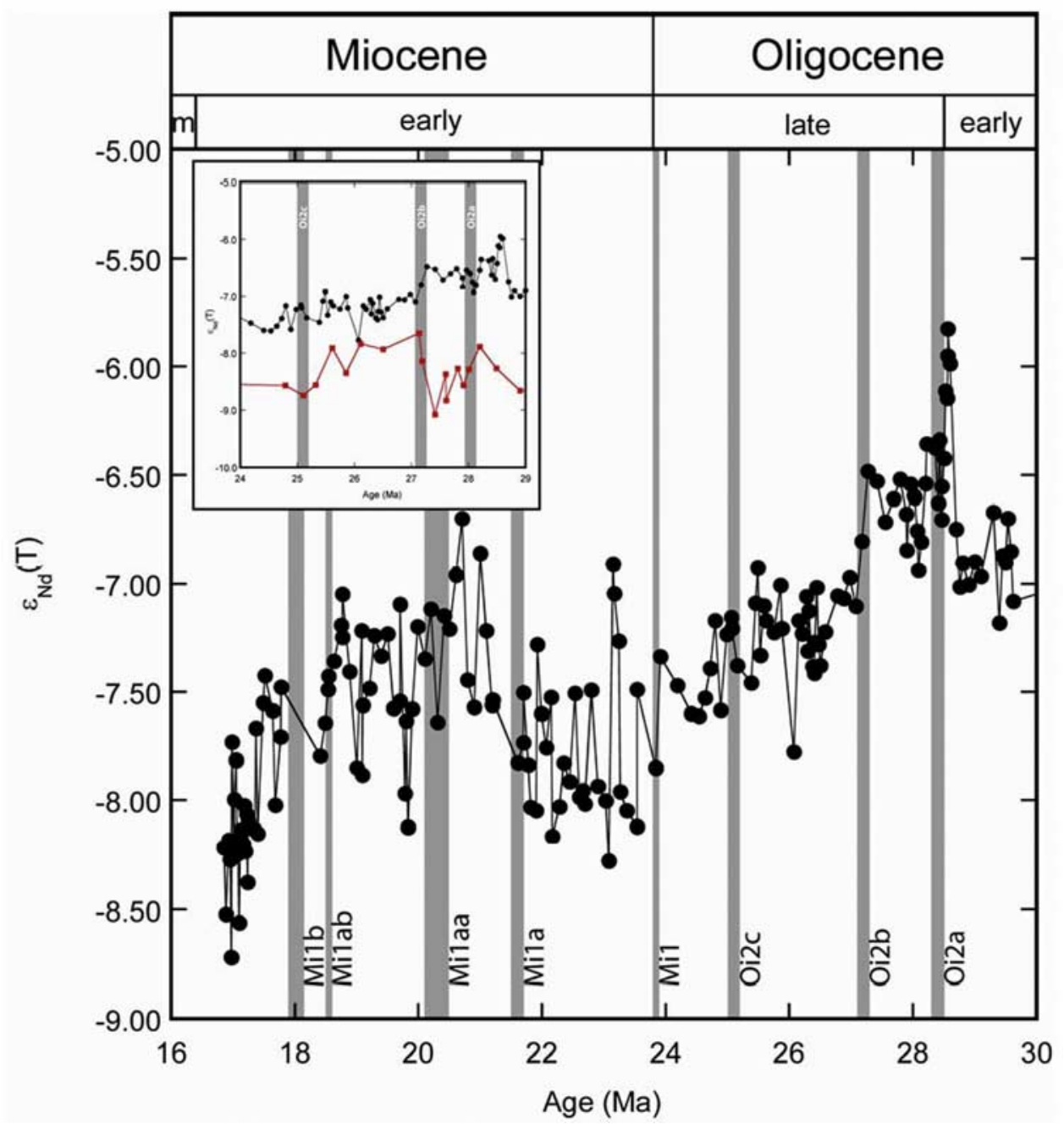

Figure 5. The $\varepsilon_{\mathrm{Nd}}(\mathrm{T})$ values from this study, relative to major glaciations on Antarctica. The ages of Oligocene and Miocene glaciations are from Miller et al. [1998]. The early to late Oligocene interval is expanded in the inset, shown along with $\varepsilon_{\mathrm{Nd}}$ values from upper Maud Rise.

[18] Relative to the long-term trend, prominent decreases in $\varepsilon_{\mathrm{Nd}}$ values occur at 27.3 Ma and 23.9 Ma. These intervals coincide with $\mathrm{Oi} 2 \mathrm{~b}$ and Mil glaciations, respectively (Figure 5). Decreasing $\varepsilon_{\mathrm{Nd}}$ values continue for a few million years following Oi2b, but this is not the case following Mil. It is possible that the large decrease at 27.3 Ma and the subsequent decrease through the late Oligocene is related to weathering associated with the Oi2b glaciation. However, $\varepsilon_{\mathrm{Nd}}$ at upper Maud Rise (ODP Site 689) [Scher and Martin, 2004] does not reflect this purported input, but instead shifts toward more radiogenic values during Oi2b (Figure 5, inset). The contrast between these sites argues against weathering as the cause of $\varepsilon_{\mathrm{Nd}}$ changes during the Oi2b glaciation. Maud Rise was closer to Antarctica and presumably more sensitive to inputs from glacial weathering of Antarctic basement. Moreover, other glaciations of similar or greater magnitude (e.g., Oi2a, Oi2c) do not coincide with major $\varepsilon_{\mathrm{Nd}}$ inflections at Agulhas Ridge, and some prominent shifts to less radiogenic values do not coincide with major glaciations (e.g., decreasing trend from 27 to $23.5 \mathrm{Ma}$ and at $17.4 \mathrm{Ma}$ ). Overall, the long-term $\varepsilon_{\mathrm{Nd}}$ variability at Agulhas Ridge does not show a systematic relationship with glaciations during the Oligocene and Miocene, suggesting the decreasing trend was not driven by weathering inputs derived from the glacial intervals.

\subsubsection{Role of Water Mass Mixing}

[19] Assuming that the $\varepsilon_{\mathrm{Nd}}$ variations at Agulhas Ridge are dominated by water mass mixing, this record provides critical constraints on the interocean exchange of deep water during the Oligocene and Miocene. Results from this study are compared to Oligocene and Miocene $\varepsilon_{\mathrm{Nd}}$ records of deep water in the North Atlantic, South Atlantic, Southern, and Indian Oceans in order to evaluate possible pathways for deep water flow into and out of the Atlantic sector (Figure 6). Water masses in most of these regions had less radiogenic $\varepsilon_{\mathrm{Nd}}$ than Agulhas Ridge over the investigated interval, and may have contributed to the long-term decreasing trend through water mass mixing. 

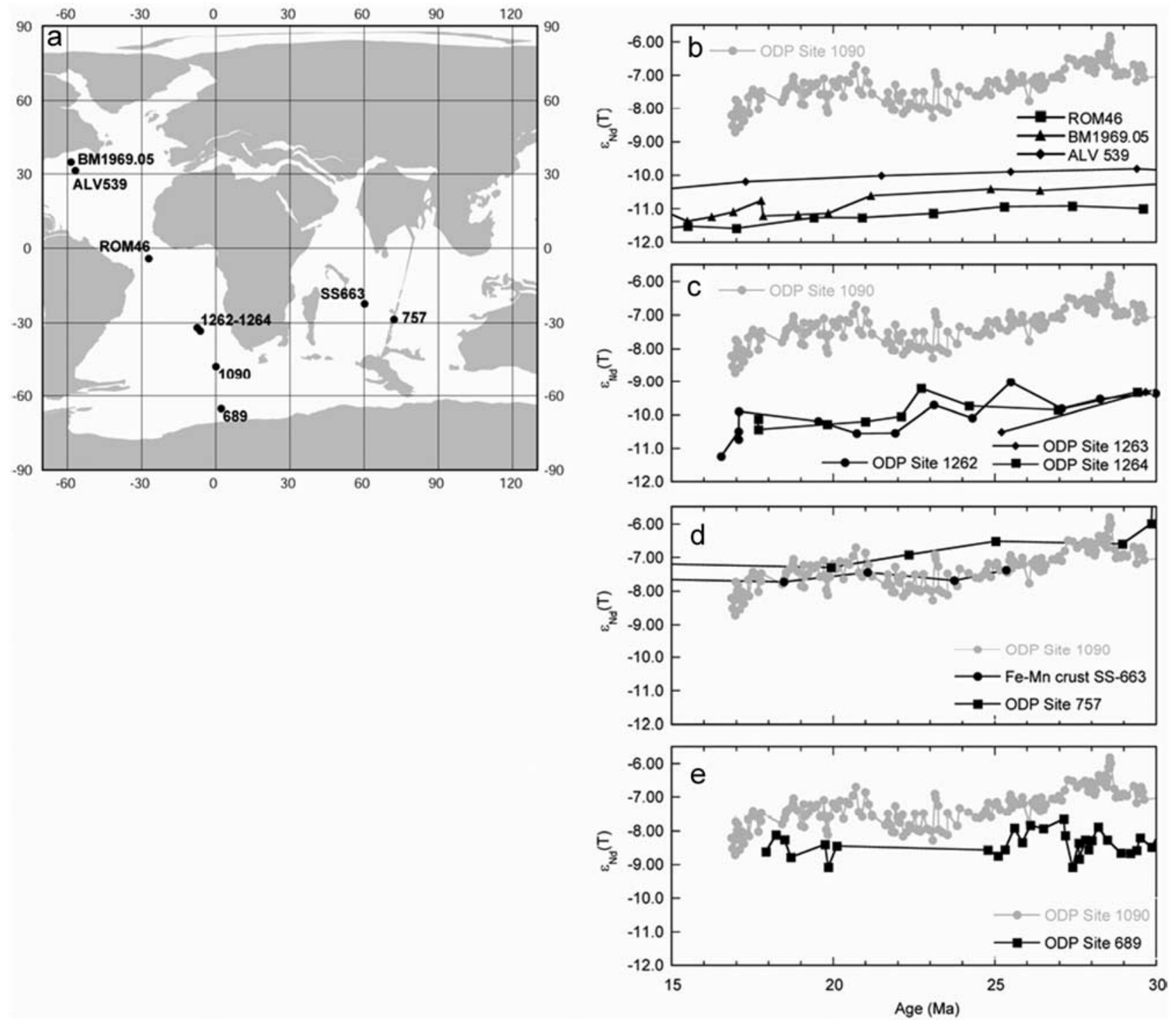

Figure 6. The $\varepsilon_{\mathrm{Nd}}(\mathrm{T})$ values from this study, relative to $\varepsilon_{\mathrm{Nd}}$ values for (b) the North Atlantic, (c) Walvis Ridge, (d) Indian Ocean, and (e) Maud Rise. (a) Locations on a 25-Ma plate tectonic reconstruction.

[20] The $\varepsilon_{\mathrm{Nd}}$ of seawater in the Atlantic Ocean decreased from north to south during the Oligocene and Miocene. The least radiogenic water mass over the investigated interval was in the North Atlantic, with values around -11 [Burton et al., 1997; O'Nions et al., 1998; Frank et al., 2003] (Figure 6a). Walvis Ridge $\varepsilon_{\mathrm{Nd}}$ was -9 in the early Oligocene and decreased to -11 by the early Miocene (Figure 6b), which has been attributed to the southward penetration of NCW into the South Atlantic [Via and Thomas, 2006]. Agulhas Ridge $\varepsilon_{\mathrm{Nd}}$ values (this study) are the most radiogenic values reported in the Atlantic, probably due to the proximity of Drake Passage inflow from the Pacific. Thus the suite of Atlantic Ocean $\varepsilon_{\mathrm{Nd}}$ records reflect mixing between northern (less radiogenic) and southern (more radiogenic) sourced water masses and the pattern suggests that an important component of flow in the Atlantic was from north to south. Agulhas and Walvis
Ridge $\varepsilon_{\mathrm{Nd}}$ records show roughly parallel long-term decreasing trends (Figure $6 \mathrm{~b}$ ), which suggests that the two locations had a similar water mass history. Thus it is possible that the long-term decreasing trend observed in this study reflects the increasing contribution of $\mathrm{NCW}$ to the Southern Ocean.

[21] On the basis of the comparison of $\mathrm{Nd}$ isotope records, it is also possible that the export of Indian Ocean water to the Atlantic sector resulted in the observed decreasing trend. However, the direction of deep water flow between the Atlantic and Indian sectors has been difficult to ascertain. This question has been addressed previously using other proxies. On the basis of $\delta^{18} \mathrm{O}$ values from benthic foraminifers in upper Oligocene sediments of ODP Site 1090, Billups et al. [2002] concluded that there were distinct water masses in the Atlantic sector and Indian Ocean during the late Oligocene. The results of this study 
suggest the opposite situation. A Fe-Mn crust from the deep western Indian Ocean (SS-663) [O'Nions et al., 1998] indicates $\varepsilon_{\mathrm{Nd}}$ values that were very similar to Agulhas Ridge (Figure 6c), which suggests efficient exchange of deep water between the Atlantic sector and the Indian Ocean. To address the question of whether water was flowing from the Atlantic into the Indian or vice versa, the Agulhas Ridge $\varepsilon_{\mathrm{Nd}}$ record is compared to $\varepsilon_{\mathrm{Nd}}$ at ODP Site 757 (Ninetyeast Ridge) [Martin and Scher, 2006]. Ninetyeast Ridge shows an overall structure similar to Agulhas Ridge, with slightly more radiogenic values due to Indonesian Seaway throughflow from the Pacific (Figure 6c).

[22] There are two possible interpretations based on this comparison, with opposite implications for deep water circulation between the Atlantic sector and the Indian Ocean. The first is that Agulhas Ridge $\varepsilon_{\mathrm{Nd}}$ reflects mixing between Indian Ocean and North Atlantic derived deep water masses. There may have been a warm and saline deep water mass that originated in the Tethys Sea and influenced the Southern Ocean [e.g., Kennett and Stott, 1990], however if such a water mass existed it did not influence the temperature of deep waters at Agulhas Ridge, which were colder than in the Indian Ocean [Billups et al., 2002]. The study of Diekmann et al. [2004] suggested that Indian Ocean seawater was deflected around Africa as the Tethys Sea closed, which could have injected Indian waters into the Atlantic sector. If this current was similar to the modern Agulhas current, the depth of this injection was probably much shallower than the Oligocene paleodepth of the study site $(3700 \mathrm{~m})$, and is unlikely to have directly influenced deep Agulhas Ridge. Furthermore, $\varepsilon_{\mathrm{Nd}}$ at upper Maud Rise does not reflect an Indian source (Figure 6d), suggesting that if deep Indian Ocean water did flow into the Atlantic, it did not influence upper Maud Rise in the Oligocene. However, the most critical problem with this interpretation is that it lacks a mechanism to explain decreasing $\mathrm{Nd}$ isotope compositions in the Indian Ocean. The second mixing scenario, that $\varepsilon_{\mathrm{Nd}}$ values at Ninetyeast Ridge reflect mixing between circumpolar and Pacific water masses, provides a more robust explanation of the available data. This scenario provides a mechanism to explain the decreasing trend at Ninetyeast Ridge, that is progressively less radiogenic $\varepsilon_{\mathrm{Nd}}$ resulting from an increase of NCW within circumpolar waters. If this second interpretation is correct, it suggests that deep water flowed from the Southern Ocean into the Indian Ocean during the Oligocene.

\subsection{Short-Term Increases: Radiogenic Sources}

[23] The long-term decreasing trend is interrupted twice, once across the early/late Oligocene boundary and again in the early Miocene. During both of these intervals $\varepsilon_{\mathrm{Nd}}$ values at Agulhas Ridge overlap with the range for Pacific seawater (see Figure 4). By the late Oligocene, the Atlantic sector was probably under the influence of several water masses: (1) SODW, (2) NCW exported from the north Atlantic, (3) Pacific waters entering via Drake Passage, and possibly (4) Indian Ocean derived waters. Only the Pacific end-member had significantly more radiogenic $\varepsilon_{\mathrm{Nd}}$ than
Agulhas Ridge over this interval. A change in the proportion of these end-members, or a change in the $\varepsilon_{\mathrm{Nd}}$ value of any of these end-members, would have influenced the $\varepsilon_{\mathrm{Nd}}$ recorded at Agulhas Ridge. To interpret increasing $\varepsilon_{\mathrm{Nd}}$ values at Agulhas Ridge, the following question is considered. Is it more likely that: (1) a contributing water mass shifted toward more radiogenic values at its source, (2) the proportion of a nonradiogenic water mass in the Atlantic sector (e.g., NCW or SODW) decreased, or (3) the proportion of Pacific waters in the Atlantic sector increased?

[24] There is no evidence for a radiogenic shift in any of the contributing water masses; in fact all of the end-member $\varepsilon_{\mathrm{Nd}}$ compositions decreased or remained constant over this interval (Figures 4 and 6), making the first option difficult to support with data from the literature. Moreover, it is difficult to find evidence for a decrease in the proportion of a nonradiogenic water mass, the second option. First, results from the study of Via and Thomas [2006] for sites located farther north suggest that the proportion of NCW in the south Atlantic was increasing steadily over this interval. It is possible, however, that the southern boundary of NCW was located between Walvis Ridge and Agulhas Ridge, in which case small changes in the southern extent of NCW might have produced the observed effect at Agulhus Ridge. Second, if SODW or the possible Indian source was present in the Atlantic sector, it is unlikely that their influence was large enough to elicit a response through reduction. For example, Maud Rise and Agulhas Ridge $\varepsilon_{\mathrm{Nd}}$ records exhibit different patterns of variability over the investigated interval (Figure 6d), suggesting that SODW had a weak influence at Agulhas Ridge during the Oligocene.

[25] On the other hand, two lines of evidence support the third option; that the contribution of Pacific water increased during these two intervals. During the first interval, the shift to radiogenic values coincides with an increase in opal mass accumulation rates (MAR) and the opal/lithogenic ratio at this site (Figure 7) [Diekmann et al., 2004]. An increase in opal MAR may have been a response to increased wind driven upwelling as continental barriers were removed from Drake Passage. During the second interval $\varepsilon_{\mathrm{Nd}}$ values begin to increase just after the Oligocene/Miocene boundary, a time of increased bottom current speeds in the circumAntarctic [Pfuhl and McCave, 2005; Lyle et al., 2007]. Both of these observations are consistent with an increased flux of Pacific water through Drake Passage.

\subsection{Development of the $\mathrm{ACC}$ and the Thermohaline Transition}

[26] $\mathrm{Nd}$ isotope results from this study outline a two step development of the ACC during the Oligocene and Miocene that is superimposed on a long-term increase in the export of NCW to the Southern Ocean. Recent studies based on evidence for erosion of the seafloor in the circum-Antarctic have placed onset of a deep ACC close to the Oligocene/ Miocene boundary [Pfuhl and McCave, 2005; Lyle et al., 2007]. The results of this study are in excellent agreement with these estimates; but capture a more detailed history of ocean circulation changes resulting from the tectonic development of Drake Passage. 


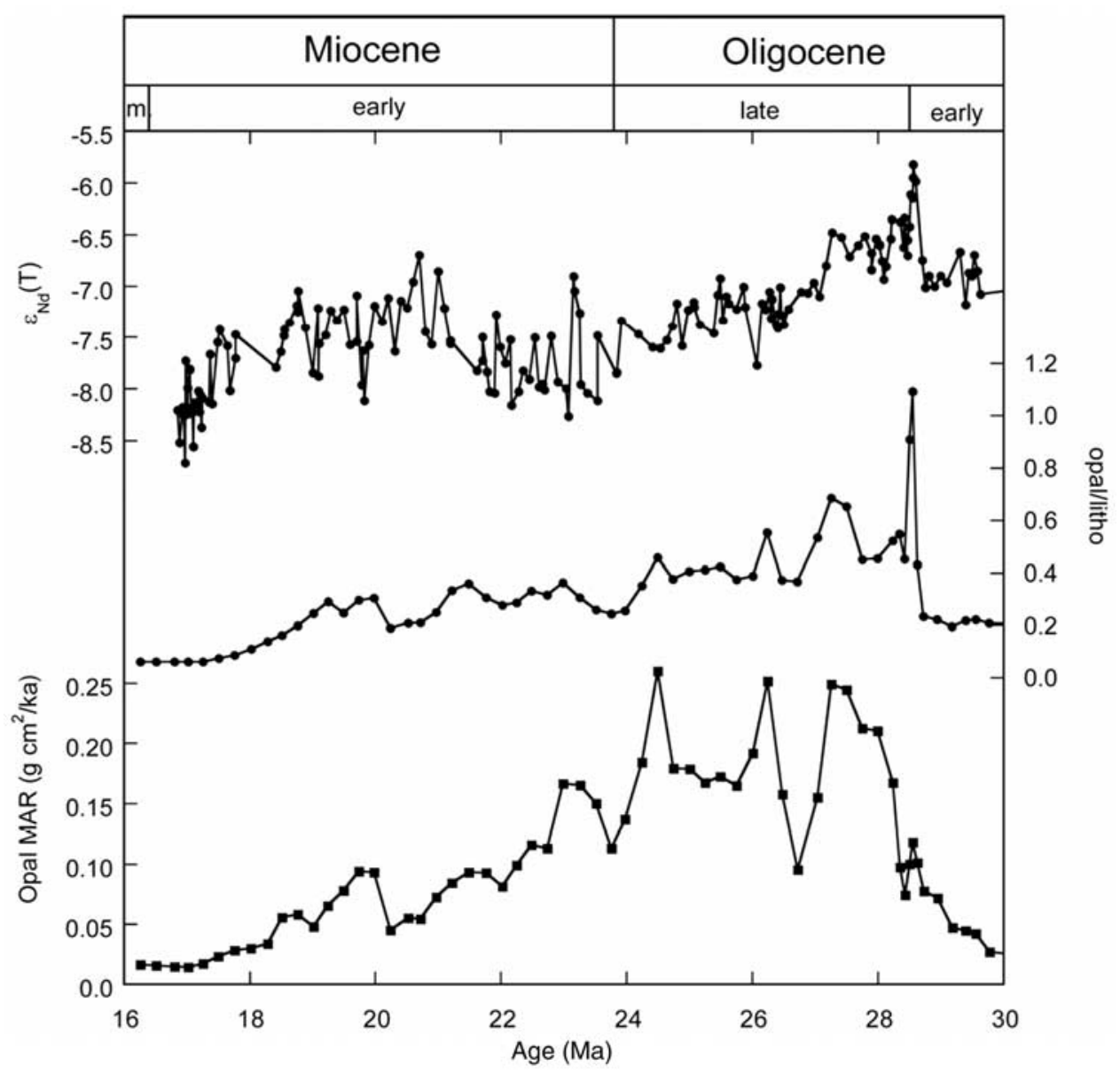

Figure 7. The $\varepsilon_{\mathrm{Nd}}(\mathrm{T})$ values from this study plotted with sedimentological data from ODP Site 1090, taken from Diekmann et al. [2004].

[27] The Nd isotope results suggest that influx of Pacific seawater through Drake Passage began to increase in the early Oligocene following the initial opening in the Eocene [Scher and Martin, 2006]. This finding is in agreement with tectonic reconstructions that show the dispersal of continental fragments from Drake Passage after $30 \mathrm{Ma}$, leading to a deep passageway [Livermore et al., 2007]. It also appears that the flux of Pacific water through Drake Passage was accompanied by an increase in upwelling, probably due to the removal of continental barriers from the wind field that drives Ekman divergence in the Southern Ocean. The long-term increase in NCW flow to the Southern Ocean follows the dispersal, and continues on through the event at the Oligocene/Miocene boundary, which caused seafloor erosion and further increases in Drake Passage throughflow. Furthermore, the influence of SODW at Agulhas Ridge appears to have diminished during the Oligocene, based on the distinct pattern of variability relative to upper Maud Rise.

[28] On the basis of the timing of these events, it is possible that increased export of NCW to the Southern Ocean was a response to the opening of Drake Passage and ACC evolution through the causal mechanisms suggested by the numerical models of Mikolajewicz et al. [1993] and Toggweiler and Samuels [1993, 1995]. In these models, Drake Passage opening increased NCW export to the Southern Ocean owing to reduced outflow of SODW and enhanced Southern Ocean upwelling, respectively. Results from this study indicate that SODW had a weak influence at Agulhas Ridge and that tectonic events in Drake Passage, probably leading to increased upwelling, preceded an increase in NCW in the Southern Ocean. Thus these findings have important implications for the factors leading to the thermohaline transition during the Oligocene.

\section{Conclusions}

[29] The Nd isotopic record from ODP Site 1090 on Agulhas Ridge records changes in the water mass composition of deep waters in the Southern Ocean in response to a pronounced reorganization of deep water circulation during the Oligocene and Miocene. Agulhas Ridge $\varepsilon_{\mathrm{Nd}}$ values are more radiogenic relative to North and South Atlantic locations over the interval examined and provide a useful constraint for evaluating interocean exchange of seawater. Water mass mixing in the Atlantic took place between a northern water mass with a less radiogenic composition and 
a southern water mass with a more radiogenic composition. The long-term decreasing trend at Agulhas Ridge that is mirrored at Walvis Ridge (South Atlantic) and Ninetyeast Ridge (Indian Ocean) suggests that export of NCW from the north Atlantic to the Southern Ocean increased during the Oligocene and Miocene. Efficient exchange of seawater between the Atlantic sector and the Indian Ocean is also supported by these data. The variability of $\varepsilon_{\mathrm{Nd}}$ values at Agulhas Ridge is distinct from upper Maud Rise (Southern Ocean), which strongly indicates that the influence of SODW diminished during the Oligocene.

[30] The development of the ACC is also reflected in the results from this study. Shifts toward more radiogenic compositions, indicating an increase in the proportion of Pacific seawater, occur around the early/late Oligocene boundary and the Oligocene/Miocene boundary. These shifts are probably related to the development of a deep passageway through Drake Passage. The relative timing of the maturation of the ACC, reduction of SODW influence, and increased export of NCW to the Southern Ocean supports causal mechanisms that relate the onset of deep water production in the North Atlantic to the opening of Drake Passage.

[31] Acknowledgments. Special thanks go to Gerald Dickens for his editorial handling and detailed comments, which greatly improved this manuscript. Comments by Sidney Hemming and two anonymous reviewers were extremely helpful, as were discussions with Linda Anderson, Steven Bohaty, Margaret Delaney, and Matt Huber. Jessica Lyons assisted with preparation of fish tooth samples. Ann Heatherington and Ray Thomas are gratefully acknowledged for their unwavering analytical and technical support. This research used samples and data from the Ocean Drilling Program, which is sponsored by the U.S. National Science Foundation (NSF) and participating countries under the management of Joint Oceanographic Institutions. Funding for this work comes from an NSF Career award to E. E. M. (OCE-962970).

\section{References}

Barker, P. F. (2001), Scotia Sea regional tectonic evolution: Implications for mantle flow and palaeocirculation, Earth Sci. Rev., 55, 1-39.

Berggren, W. A., et al. (1995), A revised Cenozoic geochronology and chronostratigraphy: Geochronology, time scales and global stratigraphic correlation, Spec. Publ. SEPM Soc. Sediment. Geol., 54, 129-212.

Billups, K., et al. (2002), Late Oligocene to early Miocene geochronology and paleoceanography from the subantarctic South Atlantic, $\mathrm{Pa}$ leoceanography, 17(1), 1004, doi:10.1029 2000PA000568.

Boyle, E. A. (1981), Cadmium, zinc, copper and barium in foraminifera tests, Earth Planet. Sci. Lett., 53, 11-35.

Boyle, E. A., and L. D. Keigwin (1985), Comparison of Atlantic and Pacific paleochemical records for the last 215,000 years: Changes in deep ocean circulation and chemical inventories, Earth Planet. Sci. Lett., 76, 135-150.

Broecker, W. S. (1991), The great ocean conveyor, Oceanography, 4, 79-89.

Burton, K. W., et al. (1997), Closure of the Central American Isthmus and its effect on deepwater formation in the North Atlantic, Nature, 386, 382-385.

Cande, S. C., and D. V. Kent (1995), Revised calibration of the geomagnetic polarity timescale for the Late Cretaceous and Cenozoic, J. Geophys. Res., 100, 6093-6095.

Channell, J. E. T., et al. (2003), Eocene to Miocene magnetostratigraphy, biostratigraphy, and chemostratigraphy at ODP Site 1090 (subAntarctic South Atlantic), Geol. Soc. Am. Bull., 115, 607-623.

Davies, R., et al. (2001), Early Oligocene initiation of North Atlantic Deep Water formation, Nature, 410, 917-920.

DePaolo, D. J., and G. J. Wasserburg (1976), Nd isotopic variations and petrogenetic models, Geophys. Res. Lett., 3, 249-252.

Diekmann, B., et al. (2004), Middle Eocene to early Miocene environmental changes in the sub-Antarctic Southern Ocean: Evidence from biogenic and terrigenous depositional pattern at ODP Site 1090, Global Planet. Change, 40, $295-313$
Eagles, G., et al. (2006), Small basins in the Scotia Sea: The Eocene Drake Passage gateway, Earth Planet. Sci. Lett., 242, 343-353.

Frank, M. (2002), Radiogenic isotopes: Tracers of past ocean circulation and erosional input, Rev. Geophys., 40(1), 1001, doi:10.1029/ 2000RG000094.

Frank, M., et al. (2002), North Atlantic Deep Water export to the Southern Ocean ove the past 14 Myr: Evidence from $\mathrm{Nd}$ and $\mathrm{Pb}$ isotopes in ferromanganese crusts, Paleoceanography, 17(2), 1022, doi:10.1029 2000PA000606.

Frank, M., et al. (2003), Evolution of deepwater mixing and weathering inputs in the central Atlantic Ocean over the past 33 Myr, Paleoceanography, 18(4), 1091, doi:10.1029/ 2003PA000919.

Frank, M., et al. (2006), $\mathrm{Nd}$ and $\mathrm{Pb}$ isotope evolution of deep water masses in the eastern Indian Ocean during the past $33 \mathrm{Myr}$, Chem. Geol., 226, 264-279.

Galeotti, S., et al. (2002), Middle Eocene-early Pliocene Subantarctic planktic foraminiferal biostratigraphy of Site 1090, Mar. Micropaleontol., 45, 357-381.

Ganachaud, A., and C. Wunsch (2000), Improved estimates of global ocean circulation, heat transport and mixing from hydrographic data, Nature, 408, 453-457.

Gersonde, R., et al. (1999a), Leg 177 summary: Southern Ocean paleoceanography, Proc Ocean Drill. Program Initial Rep., 177, doi:10.2973/odp.proc.ir.177.101.1999. (Available at http://www-odp.tamu.edu/publications/ 177_IR/CHAP_01/Output/)

Gersonde, R., et al. (1999b), Site 1090, Proc Ocean Drill. Program Initial Rep., 177 doi:10.2973/odp.proc.ir.177.105.1999. (Available at http://www-odp.tamu.edu/publications/ 177 IR/CHAP 105/Output/)

Hartnady, C. J. H. Southern ocean hotspot tracks and the Cenozoic absolute motion of the African, Antarctic, and South American plates, Earth Planet. Sci. Lett., 75, 245-257.

Hellerman, S., and M. Rosenstein (1983), Normal monthly wind stress over the world ocean with error estimates, J. Phys. Oceanogr., 13, $1093-1104$

Jeandel, C. (1993), Concentration and isotopic composition of $\mathrm{Nd}$ in the South Atlantic Ocean, Earth Planet. Sci. Lett., 117, 581-591.

Kennett, J. P., and L. D. Stott (1990), Proteus and Proto-Oceanus: Ancestral Paleogene oceans as revealed from Antarctic stable isotopic results: ODP Leg 113, Proc. Ocean Drill. Program Sci. Results, 113, 865-880.

Ling, H. F., et al. (1997), Evolution of $\mathrm{Nd}$ and $\mathrm{Pb}$ isotopes in Central Pacific seawater from ferromanganese crusts, Earth Planet. Sci. Lett., 146, 1-12.

Livermore, R., et al. (2007), Drake Passage and Cenozoic climate: An open and shut case? Geochem. Geophys. Geosyst., 8, Q01005, doi:10.1029/2005GC001224.

Lyle, M., et al. (2007), Late Oligocene initiation of the Antarctic Circumpolar Current: Evidence from the South Pacific, Geology, 35, 691-694.

Martin, E. E., and B. A. Haley (2000), Fossil fish teeth as proxies for seawater $\mathrm{Sr}$ and $\mathrm{Nd}$ isotopes, Geochim. Cosmochim. Acta, 64, $835-847$.

Martin, E. E., and H. D. Scher (2004), Preservation of seawater $\mathrm{Sr}$ and $\mathrm{Nd}$ isotopes in fossi fish teeth: Bad news and good news, Earth Planet. Sci. Lett., 220, 25-39.

Martin, E. E., and H. Scher (2006), A Nd isotopic study of southern sourced waters and Indonesian throughflow at intermediate depths in the Cenozoic Indian Ocean, Geochem. Geophys. Geosyst., 7, Q09N02, doi:10.1029/ 2006GC001302.

Mikolajewicz, U., et al. (1993), Effect of Drake and Panamanian gateways on the circulation of an ocean model, Paleoceanography, 8 , $409-426$.

Miller, K. G., et al. (1987), Tertiary oxygen isotope synthesis, sea level history, and continental margin erosion, Paleoceanography, 2, 119

Miller, K. G., et al. (1991), Unlocking the Ice House: Oligocene-Miocene oxygen isotopes, eustacy, and margin erosion, J. Geophys. Res., 96, 6829-6848. 
Miller, K. G., G. S. Mountain, J. V. Browning, M. Kominz, P. J. Sugarman, N. Christie-Blick M. E. Katz, and J. D. Wright (1998), Cenozoic global sea level, sequences, and the New Jersey transect: Results from coastal plain and continental slope drilling, Rev. Geophys. 36(4), 569-602.

O’Nions, R. K., et al. (1998), Secular variation of $\mathrm{Nd}$ and $\mathrm{Pb}$ isotopes in ferromanganese crusts from the Atlantic, Indian and Pacific oceans, Earth Planet. Sci. Lett., 155, 15-28.

Pak, D. K., and K. G. Miller (1992), Paleocene to Eocene benthic foraminiferal isotopes and assemblages: Implications for deepwater circulation, Paleoceanography, 7, 405-422.

Pfuhl, H. A., and I. N. McCave (2005), Evidence for late Oligocene establishment of the Antarctic Circumpolar Current, Earth Planet. Sci. Lett., 235, 715-728.

Piepgras, D. J., and S. B. Jacobsen (1988), The isotopic composition of neodymium in the North Pacific, Geochim. Cosmochim. Acta 52, 1373-1381.

Piepgras, D. J., and G. J. Wasserburg (1987), Rare earth element transport in the western North Atlantic inferred from Nd isotopic observations, Geochim. Cosmochim. Acta, 51, $1257-1271$

Ravizza, G., and B. Peucker-Ehrenbrink (2003), The marine $187 \mathrm{Os} / 188 \mathrm{Os}$ record of the Eocene-Oligocene transition: The interplay of weathering and glaciation, Earth Planet. Sci. Lett., 210, $151-165$.

Rosenthal, Y., et al. (1997), Last Glacial Maximum paleochemistry and deepwater circulation in the Southern Ocean: Evidence from foraminiferal cadmium, Paleoceanography, 12, 787-796

Roy, M., et al. (2007), ${ }^{40} \mathrm{Ar} /{ }^{39} \mathrm{Ar}$ ages of Hornblende Grains and Bulk Sm/Nd Isotopes of Circum-Antarctic Glacio-marine Sediments:
Implications for Sediment Provenance in the Southern Ocean, Chem. Geol., 244, 507-519, doi:10.1016/j.chemgeo.2007.1007.1017.

Scher, H. D., and E. E. Martin (2004), Circulation in the Southern Ocean during the Paleogene inferred from neodymium isotopes, Earth Planet. Sci. Lett., 228, 391-405.

Scher, H. D., and E. E. Martin (2006), Timing and climatic consequences of the opening of Drake Passage, Science, 312, 428-430.

Stickley, C. E., et al. (2004), Timing and nature of the deepening of the Tasmanian Gateway, Paleoceanography, 19, PA4027, doi:10.1029/ 2004PA001022.

Stommel, H. (1958), The abyssal circulation, Deep Sea Res., 5, 80-82.

Thomas, D. J. (2004), Evidence for deep-water production in the North Pacific Ocean during the early Cenozoic warm interval, Nature, $430,65-68$

Thomas, D. J., and R. K. Via (2007), Neogene evolution of Atlantic thermohaline circulation: Perspective from Walvis Ridge, southeastern Atlantic Ocean, Paleoceanography, PA2212, doi:10.1029/2006PA001297.

Thomas, D. J., et al. (2003), Neodymium isotopic reconstruction of late Paleocene-early Eocene thermohaline circulation, Earth Planet. Sci. Lett., 209, 309-322.

Toggweiler, J. R., and B. Samuels (1993), Is the magnitude of the deep outflow from the Atlantic Ocean actually governed by Southern Hemisphere winds, in The Global Cycle, edited by M. Heimann, pp. 303-331, Springer, Berlin.

Toggweiler, J. R., and B. Samuels (1995), Effect of Drake Passage on the global thermohaline circulation, Deep Sea Res., Part I, 42, 477 500

van de Flierdt, T., et al. (2004), Deep and bottom water export from the Southern Ocean to the
Pacific over the past 38 million years, Paleoceanography, 19, PA1020, doi:10.1029/ 2003PA000923.

van de Flierdt, T., et al. (2007), Global neodymium-hafnium isotope systematics - Revisited, Earth Planet. Sci. Lett., 259, 432-441.

Via, R. K., and D. J. Thomas (2006), Evolution of Atlantic thermohaline circulation: Early Oligocene onset of deep-water production in the North Atlantic, Geology, 34, 441-444.

Weiss, R. F., et al. (1979), Geochemical studies of the Weddell Sea, Deep Sea Res., Part A, 26, $1093-1120$.

Wildeboer Schut, E., et al. (2002), Seismic evidence for bottom current activity at the Agulhas Ridge, Global Planet. Change, 34, $185-$ 198.

Wright, J. D., and K. G. Miller (1993), Southern Ocean influences on late Eocene to Miocene deepwater circulation, in The Antarctic Paleoenvironment: A Perspective on Global Change Part 2, Antarct. Res. Ser., vol. 60 edited by J. P. Kennett and D. A. Warnke, pp. 1-25, AGU, Washington, D. C.

Zachos, J. C., et al. (1999), Early Cenozoic glaciation, Antarctic weathering, and seawater ${ }^{87} \mathrm{Sr} /{ }^{86} \mathrm{Sr}$ : Is there a link?, Chem. Geol., 161, $165-180$.

Zachos, J., et al. (2001), Trends, rhythms, and aberrations in global climate $65 \mathrm{Ma}$ to present, Science, 292, 686-693.

E. E. Martin, Department of Geological Sciences, University of Florida, Gainesville, FL 32611, USA.

H. D. Scher, Ocean Sciences Department, Institute of Marine Sciences, University of California, Santa Cruz, 1156 High Street, Santa Cruz, CA 95064, USA. (howie@ucsc.edu) 